\title{
Organizational Culture and Entrepreneurial Orientation: Mediating Role of Entrepreneurial Leadership
}

\author{
Chaudry Bilal Ahmad Khan ${ }^{1}$, Riaz Ahmed ${ }^{2}$
}

\begin{abstract}
The purpose of this study was to investigate the mediating role of entrepreneurial leadership between different types of organizational cultures and entrepreneurial orientation. A total of 181 online responses from the small and medium size industries were gathered with the help of chamber of commerce and were analyzed using Partial Least Square (PLS). The result revealed that adhocracy culture and clan culture significantly affected the entrepreneurial orientation only if entrepreneurial leadership style acted as a mediator showing innovative solution development and mentorship were highly dependent on entrepreneurial leadership style. However, the relationship between market culture and entrepreneurial orientation became insignificant with the mediation of entrepreneurial leadership showing lack of external focus towards the market. The role of entrepreneurial leadership style remained significant in hierarchical culture to enhance entrepreneurial orientation suggesting higher internal focus and control. This study will help researchers and practitioners to understand the entrepreneurial leadership style in different organizational perspectives to generate entrepreneurial orientation.
\end{abstract}

Keywords: Entrepreneurial leadership; entrepreneurial orientation; organizational culture; small and medium size industries.

\section{Introduction}

Entrepreneurship has been under study for past several years. To perform in a competitive market environment, it is necessary that the entrepreneurs have appropriate characteristics to compete with the market. These characteristics consists of innovative ideas, risk propensity to take the decision and proactive approach towards the changing market, when all three combined are also known as entrepreneurial orientation.

1 PhD Student, Department of Management Sciences, Bahria University, Islamabad, Pakistan; Assistant Professor, Department of Electrical Engineering, Institute of Space Technology, Islamabad, Pakistan Email:bilal.khan@ist.edu.pk

2 Associate Professor, Department of Management Sciences, Bahria University, Islamabad, Pakistan. Email:rahmed.buic@bahria.edu.pk

\begin{tabular}{ll} 
ARTICLE HISTORY & \\
04 Feb, 2019 Submission Received & 19 Mar, 2019 First Review \\
\hline 22 Jun, 2019 Second Review & 13 Sep, 2019 Third Review \\
\hline 10 Oct, 2019 Accepted &
\end{tabular}


Business performance in the new ventures and established firms depend on entrepreneurial orientation of the leadership and the firm employees (Su, Xie, \& Li, 2011). Entrepreneurial orientation is a multidimensional construct which mainly refers to processes, practices and decision making (Holland \& Shepherd, 2013). Therefore, the ability of the entrepreneurs to apply the previous knowledge and educate themselves for better strategy making becomes very necessary. Entrepreneurial orientation helps in developing the strategy to compete in the market. The practices like developing a strategy and avoiding risks (Kan \& Tsai, 2006; Macko \& Tyszka, 2009) through better decision making are also the factors for being successful in business. It depends on an entrepreneurs how closely they observe their environment, gain information from it and take the action appropriately (Kreiser, 2011). Gaining the information from the environment is usually done collectively rather than individually and depends largely on the culture demonstrated by any organization.

To get entrepreneurially oriented, members within the organizational system interact with each other and their surroundings to learn from it. The thinking and cognition of each member is influenced by public and private world forming culture of the organization (Lakomski, 2001; Zahari \& Shurbagi, 2012). Organizational culture also depends on the policies and operating procedure already set in the organization. In fact, these policies and operational procedures of the organization already laid down, impact the thinking process and behavior of the individuals. Looking at the larger picture, organizational culture is the formulation of dyadic relationship of individuals and policies or operational procedures, where both, individuals and organizational policies have an impact on each other (Weberg, 2013). This makes the organization as a complex system (Dooley, 1997) where organizational culture can be dynamically be formed through individuals' interactions with the system and each other. In such cases, in order to evaluate the performance of an organization it becomes necessary to study the organizational culture (Cameron \& Quinn, 2011).

Leadership on the other hand plays an important role in developing the culture by defining the policies and procedures. These policies may have suitable impact on the individual's behaviors. As an entrepreneur, leadership play an important role in the performance of the business (Wayne, Shore, \& Liden, 1997). Therefore, it is important that the entrepreneurs should also be good leaders. Entrepreneurial leadership style proposed by Renko, El Tarabishy, Carsrud, and Brännback (2015) suggest that leader should be able to help and direct the group members of the organization to work on the goals established to exploit the opportunities. Leadership thus provides a pivotal role in adapting to the changes in the environment and molding the organization to the changing environment. A good entrepreneur embedded with leadership qualities, should be able to preempt the market orientation and take the decisions accordingly. 
Engelen, Flatten, Thalmann, and Brettel (2014) examined the relationship between organizational culture and entrepreneurial orientation. Studies also show significant relationship between organizational culture and leadership (E. Ogbonna \& L. C. Harris, 2000; Sarros, Cooper, \& Santora, 2008). Culture within an organization influences the employees' tendency to act and leadership essentially play a vital role in formation of culture. Previous studies on leadership such as transformational theory and trait theory (Bass \& Bass, 2009; Chiaburu, Oh, Berry, Li, \& Gardner, 2011; Chung-Wen, 2008) suggests behaviors and traits of leaders which influence entrepreneurial orientation (Engelen, Gupta, Strenger, \& Brettel, 2015). This poses a problem, as entrepreneurial orientation exhibiting process or decision making, emphasizes on actions rather than the traits and behaviors (Cogliser \& Brigham, 2004). Renko et al. (2015) suggests entrepreneurial leadership style which is aligned to the leadership and also addresses the actions related to entrepreneurs. Based on the review of previous literature, study on the role of the entrepreneurial leadership style (Fernald, Solomon, \& Tarabishy, 2005; Renko et al., 2015) in different types of organizational culture (Cameron, 1985; Cameron \& Quinn, 2011) to promote entrepreneurial orientation (Covin \& Slevin, 1989; Engelen et al., 2015) is hard to find. Renko et al. (2015) also suggests that entrepreneurial leadership style should be studied in an organizational context. Therefore, the purpose of this study is to investigate the role of entrepreneurial leadership style between the four types of organizational cultures and entrepreneurial orientation.

Current study adds the knowledge to the existing body of knowledge in two ways. First, the effect of four organizational cultures is studied for generation of entrepreneurial orientation. Each organizational culture presents a finding about the existing organizational culture in small and medium size industry. Second, the role of entrepreneurial leadership style is studied as a mediator between the four organizational cultures and entrepreneurial orientation. The paper significantly contributes to the literature by generating insight about the organizational cultures and role of entrepreneurial leadership style for fostering entrepreneurial orientation. The findings of this study will help the entrepreneurial leaders to maximize the entrepreneurial activity in their organizations. As entrepreneurial orientation increases the performance of the organizations, the study will contribute in the economic development of the small and medium size industry.

\section{Literature Review and Hypotheses}

\subsection{Entrepreneurial orientation}

The business environment keeps changing based on the market requirements. Businesses thrive for the new opportunities. This constant drive of an organization 
to handle the uncertainty in business and seek for the new opportunities constantly is known as entrepreneurial orientation (Wiklund \& Shepherd, 2005). It is up to the decision-making capabilities of the entrepreneurs which lead to the entrepreneurial actions and generate the new goods and services. It may lead the firm towards or away from the equilibrium (McMullen, Plummer, \& Acs, 2007). The entrepreneurial orientation may keep changing with experience, where more the experience is, more oriented the entrepreneur will be. The newly formed firm may have a lesser entrepreneurial orientation giving them lesser ability to identify the opportunity and take benefit from it. On the other hand the experienced firm may have better opportunity identification making them better entrepreneurially oriented ( $\mathrm{Su}$ et al., 2011). An opportunity identification becomes easy for an entrepreneur when supply and demand exists. If either of the supply or demand is missing, the entrepreneur has to create either of the sides. If the both supply and demand does not exist, the entrepreneur has to come up with both the supply and demand creating the opportunity (Sarasvathy, Dew, Velamuri, \& Venkataraman, 2003). Entrepreneurial orientation therefore, enables the opportunity recognition for the entrepreneur for consistent development and performance of the organization (Brouthers, Nakos, \& Dimitratos, 2015; Semrau, Ambos, \& Kraus, 2016).

Entrepreneurial orientation has been studied extensively for the performance of the organizations Originally entrepreneurial orientation has three dimensions: (i) Innovation, (ii) pro-activeness and (iii) risk-taking (Covin \& Slevin, 1989; Miller, 1983) which are explained below.

Innovativeness can be understood as the introduction of new products, services or processes (Leyerer, 2012; Lumpkin \& Dess, 2001). Entrepreneurs can disrupt the equilibrium of the market by introducing either new products which do not exist already in the market, by new methods of production which are unfamiliar in the market and gives production efficacy hence providing market better supply and demand, by identifying new sources of raw material being used in the production of the new or existing product, or by carrying out the new organization in itself which may create the monopoly position industry or market domination (Stevenson \& Jarillo, 1990). Innovation is therefore bringing newness in different ways where the business or firm can develop the better standing in the relevant industry. Pérez-Luño, Wiklund, and Cabrera (2011) describes the innovation as the formulation of the process or the product internally to the organization such that it is new to the market but if the organization adopts the processes or the products which have been developed elsewhere are generally new to the organization.

Proactiveness shows the behavior of the entrepreneur to seek different opportunities (Lumpkin \& Dess, 2001) and remain well informed about the continuous changes 
in the market. A proactive entrepreneur always takes a keen interest in the change in the market and follows the new opportunity or the change in the market aggressively (Zehir, Müceldili, \& Zehir, 2012). The proactiveness of an entrepreneur is linked with the behavioral intentions. A proactive entrepreneur will be more vigilant about the surrounding, will take an initiative, learn, act at the appropriate time, preserve their ideas and persist towards continuous improvement. On the other hand, people not having the proactive approach tend to show opposite patterns like failure to identify the opportunity and react to the situations when needed (Crant, 1996). Anderson, Kreiser, Kuratko, Hornsby, and Eshima (2015) while defining entrepreneurial behavior as a firm level pursuit, merged the dimensions of innovativeness and proactiveness.

An ability of an entrepreneur to either take or avoid risk for a certain situation is the risk taking ability (Forlani \& Mullins, 2000). It is the willingness of a person to accept losses from the business after the decision is made. To launch a new business or make decision for the further growth of the existing business, an entrepreneur has to take decisions with an uncertain outcome. The decisions made by the entrepreneur for a particular situation shows the behavior of the entrepreneur towards the situation. This behavior shows the risk taking ability of the entrepreneur. An entrepreneur shows better behavior towards accepting the risk rather than a non-entrepreneur (Norton $\&$ Moore, 2006) hence making entrepreneurs more risk takers.

\subsection{Organizational culture and entrepreneurial orientation}

Organizational culture is related to the behavior of the individuals working in the organization and their interactions within organization (Lawrence, Street, Quinn, \& Peter, 2009; Tong, 2015). Studies provide sound knowledge about the cultural perspective in the organizations which makes it interesting to see how different organizational cultures helps them to grow in different ways (J. B. Barney, 1986; Berson, Oreg, \& Dvir, 2008; Trice \& Beyer, 1993). Organizational culture is usually referred to the actions, procedures and protocols of the organizations (James, Choi, Ko, McNeil, Minton, Wright, \& Kim, 2008). There have been previous studies (Denison, 1996) which differentiate the organizational culture form organizational climate, however (Wallace, Hunt, \& Richards, 1999) discusses that the organizational culture and organizational climate are interlinked with each other.

Organizations are started by the single or a group of people. These people set certain norms and procedures within the organizations. These norms and procedures later form the organizational culture for the people joining later. The behavior of the organization depends upon the decisions of these initial group of members also known as leaders, who set the rules of business or the rules of operations. Leadership style being one of the pivotal factors creating organizational culture is still a debatable issue 
by researchers (Malby, 2006). The role of the leaders is to influence the people working for them and lead the organization and its stakeholders towards success making it different from management of the organization (Michael, Storey, \& Thomas, 2002). Cameron and Quinn (2011) however, discussed different organizational culture as clan culture, adhocracy culture, hierarchy culture and market-oriented culture as four types of organizational culture. These four culture types characterize different human behaviors and their decision-making criterion in different types of organizational structure. The literature on types of organizational culture shows that the adhocracy culture and market culture bring the external focus and differentiation. Clan culture and adhocracy culture brings flexibility and discretion. Clan culture and hierarchical culture brings internal focus and integration. Hierarchical culture and market culture brings stability and control (Cameron \& Quinn, 2011; Zahari \& Shurbagi, 2012). Keeping an external focus with adhocracy culture and market culture allows the organizations to identify the opportunity in the market by offering innovative solutions with minimum risk. Maintaining clan culture and adhocracy culture brings freedom to think and act, which provides better chances of creating something innovative, by proactively identifying the market gap. Maintaining internal control and hierarchical structure within the organization has been seen to negatively influence the independent thought process, innovative solution development and proactive behavior. Although hierarchical culture has been seen to restrict the independent thought process and proactive behavior, market culture does seem to support the mitigation of risk by proactive thinking.

Adhocracy culture focuses on the innovation and risk taking. The risk taking affects the individuals, encourages them to work independently and explore new opportunities which in return is good for the development of the organization (Baum \& Locke, 2004). As the thought process is independent in this culture and individuals are allowed to act independently, the individuals try new methods to solve the problems. The individuals in such cases try to acquire maximum knowledge and information which becomes the base for the new and innovative product development (Hodson, 1991; Weinstein, Przybylski, \& Ryan, 2012). Adhocracy Culture having the strategic emphasis towards the innovativeness and development of new products and services, lineate towards the entrepreneurial orientation. This organizational culture provides the members of the organizations to initiate the new methodologies to solve the existing problems (Hopkins, Tidd, Nightingale, \& Miller, 2011). In this culture the resources are used in a new way to develop the innovative solutions thus creating a relationship with the entrepreneurship and entrepreneurial efforts. This suggests that:

Hypothesis 1: Adhocracy Culture has a positive significant relationship with entrepreneurial orientation 
Clan culture emphasizes the values like loyalty, tradition and internal maintenance (Cameron, 1985). It emphasizes on the practices like facilitation or mentorship, which guides the worker on every step of the way (Cameron \& Quinn, 2011). It is therefore clear that due to the clan culture, people working in one organization know which other person is relevant for the solution thus allowing themselves to share the ideas with them. This increases the self-confidence, and improves the decision making. Participation has been found to be more significant in intrapreneurs rather than entrepreneurs (Morrison, 2007). Intrapreneurs get a support from their organizations where the organizations participate in the decisions intrapreneurs make. On the other hand, entrepreneurs may not have any organizational support and have to rely entirely on their own.

Clan culture promotes the information and knowledge, by sharing the ideas with each other (Cameron \& Quinn, 2011). However, according to Engelen et al. (2014) dependencies are produced in individuals in an organization following a clan culture. Clan culture on the other hand provides an evidence of an organizational culture which provides a support, mentorship and facilitation to the members working in the organization. This enables a good chance for the members of the organizations to share their ideas with each other. This participative nature in the organization generates the circulation of information and knowledge amongst all the members of the organization (Cameron \& Quinn, 2011). This commonly distributed information and knowledge helps the members of the organization to generate innovative and creative ideas (Floyd \& Wooldridge, 1999; Rahim, Ismail, Thurasamy, \& Abd, 2018; Somech, 2005; Weerakoon, McMurray, Rametse, \& Arenius, 2019).

Also, the organizations which support their employees for the knowledge creation and knowledge sharing for new product and services development suggests that:

Hypothesis 2: Clan Culture has a positive significant relationship with the entrepreneurial orientation

The hierarchical culture puts the processes and mechanism of the organization in focus. This culture relies basically on rules, regulations and following them the way they have been defined. This culture provides coordination with the leadership (Engelen et al., 2014) by putting rest of the members of the organization within the restrained boundaries. This harshness of the structure formulation reduces the opportunities for innovative solution development and allows an absolute control. This type of organizational culture restricts the employees in the firm to think beyond their working routine, hence limiting their thinking capability and increasing the internal focus. Hierarchical culture shows a strict following of the policies and rules in the organization. This shows that the organizations which have a strict control 
over the members of the organizations, are usually deficient in developing an open environment for the members of the organization (Nanjundeswaraswamy \& Swamy, 2014). This lack of openness restrains the individuals to express the ideas for the betterment of the organization. This restricts the members to hold back their ideas towards the development of new products and services as well (Pourmohammad \& Rezai, 2016). This suggests that:

Hypothesis 3: Hierarchical culture has a negative significant relationship with the entrepreneurial orientation

Market culture promotes production and competitiveness which comes with the strong goal orientation and exploiting the opportunities. In order to grow and remain ahead in the market the decision making is of absolute importance (J. Barney \& Zajac, 1994). The realization of the goals with respect to the changing demands of the market increases the chances of the getting better opportunities in the market, hence aiming for the growth of the firm. The firm may respond to the changing demand of the market or proactively judge the future demands (Atuahene-Gima, Slater, \& Olson, 2005). Also, to grow and gain competitive advantage in the market, the organizations seek external partners for the exchange of their resources to jointly develop a competitive edge in the market. Both these initiatives, realization of the goals with changing market and seeking external partners represents the external focus of the firm. Market culture has the focus towards the goal accomplishment, competitive action and achievement. The organizations working for the market domination, need to have the competitive edge over the other organizations (J. Barney, 1991). The competitive edge over the organizations can be achieved through the development of innovative ideas, taking risks and proactively follow the opportunity to be exploited in the market (Hughes \& Morgan, 2007). This exploitation of the market opportunity enables the organizations to sustain as a market leader which suggests that:

Hypothesis 4: Market culture has a positive significant relationship with the entrepreneurial orientation

\subsection{Entrepreneurial leadership style, organizational culture and entrepreneurial orientation}

Organizational culture is closely in relation with leadership (Ensley, Hmieleski, \& Pearce 2006; Jensen \& Luthans, 2006; Jia, Yan, Cai, \& Liu, 2018; Ogbonna \& Harris, 2000). Entrepreneurial leadership style poses a different perspective when compared with other leadership styles. Renko et al. (2015) defines the entrepreneurial leadership style as a leadership that, "Entails influencing and directing the performance of group members toward the achievement of organizational goals that involve recognizing and 
exploiting entrepreneurial opportunities" (p. 2).

Harrison, Leitch, and McAdam (2015) and Renko et al. (2015) provide a good summary of evolution of entrepreneurial leadership style (Leitch \& Volery, 2017). According to Cunningham and Lischeron (1991), entrepreneurial leadership style has been considered to set the goals, create the opportunities, maintain the intimacy amongst the group of individuals, empower the group members. Kuratko (2007) and Nicholson (1998) later suggested entrepreneurial leadership style are expected to have specific traits such as risk taking, openness and achievement oriented. Ireland, Hitt, and Sirmon (2003) concept of entrepreneurial leadership style was the ability to influence others to manage the resources appropriately such that the individuals working autonomously become opportunity seekers. Cogliser and Brigham (2004) emphasized that entrepreneurial leadership style not only should be able to identify the opportunity, but also bundle the resources for the opportunity. At the same time, Gupta, MacMillan, and Surie (2004) proposed that entrepreneurial leadership style is committed to the support necessary for exploration and exploitation of the ideas. Entrepreneurial leadership style has also been considered to be able to sustain the rapidly changing environment and adapting to the innovativeness with the changing requirements (Surie \& Ashley, 2008).

Entrepreneurial leadership style proposed by Renko et al. (2015) provides a different set of style of leadership style. Entrepreneurial leadership style includes the key elements of passion, motivation, innovativeness, creativity, bootstrapping, vision of future and risk taking. Previous studies show that entrepreneurial leadership style is considered to be important for the development of the startups (Zaech \& Baldegger, 2017). In case of the new venture, the individuals starting the venture conceptualize the new direction of the business leading it towards the new dimensions. Leadership which is combined with different ideas that leads the businesses towards the new dimensions of creativity and innovativeness is entrepreneurial leadership style (Sklaveniti, 2017). Although, entrepreneurial leadership has been tested with other leadership styles, (Amer, 2017), entrepreneurial leadership style can be differentiated from other leadership styles based on the influence on the subordinates for gaining an opportunity rather than influencing the subordinates based on the traits and behaviors (Dinh, Lord, Gardner, Meuser, Liden \& Hu, 2014). Entrepreneurial leadership style having its focus on the achievement of the organizational goals by exploitation of the opportunities, was found out to have positive influence on the individual's job performance (Miao, Eva, Newman, \& Cooper, 2017).

The role of leadership and organizational culture has been found to be essentially important for the performance of the organization (Huey Yiing \& Zaman Bin Ahmad, 2009; Zahari \& Shurbagi, 2012). It is the leadership which is considered to play an 
important role in developing the culture of any organization (Nanjundeswaraswamy $\&$ Swamy, 2014). These are the decisions of the top tier of any organization which forms a complex network of actions to provide a culture. Leadership therefore, has been studied both as an essential part of the system (Tse, Huang, \& Lam, 2013; Wang, Tsai, \& Tsai, 2014) as well as an agent which can affect the existing relationships by interacting with them (de Vries, Roe, \& Taillieu, 2002; Engelen et al., 2015).

One of the key issues that entrepreneurial leadership style emphasizes on is the exploration and exploitation of the opportunities. The exploration and exploitation of the opportunity involves the innovative solution development which result in the new product and service. The studies show that the exploration involves learning through different sources and exploitation is the experimentation in different ways to see if the already existing problem can be solved through new creative method (Hazy \& Uhl-Bien, 2015; Surie \& Hazy, 2006). Entrepreneurial leader being member of the top tier and having a vision, becomes an essential part in identifying the opportunity and then forming innovative solution. As adhocracy culture also facilitates in entrepreneurial activities, this suggests that:

Hypothesis 5: Entrepreneurial leadership style mediates the effect of adhocracy culture on entrepreneurial orientation

Another key element of the entrepreneurial leadership style is the assistance to the group members working in the organization. Entrepreneurial leaders provide the direction to their subordinates to achieve the goal that the leaders have decided. In such cases, the leaders provide support to their subordinates and guide them with the directions for any further proceedings. This supportive behavior of the leadership is considered to be important for the creativity and innovativeness in the organization ( $\mathrm{Hu}, \mathrm{Gu}, \& \mathrm{Chen}, 2013)$. This also creates a mutual dependency amongst the members of the organization which increases the firm performance (Friesenbichler \& Selenko, 2017). Tong (2015) suggests that supportive organizational environment results in transformative actions (Engelen et al., 2015) which leads towards the innovative solution development through guidance and mentorship. As the mentorship, guidance and supportive behavior is generally provided by the leadership it suggests that:

Hypothesis 6: Entrepreneurial leadership style mediates the effect of clan culture on entrepreneurial orientation

Under the circumstances where strict control of the organizations is observed, leadership shows the control and command in the authorities (De Hoogh, Greer, \& Den Hartog, 2015). As the leadership is commanding at the top and wants to control the scope and direction of the organization, leadership takes decisions and actions 
which they think are for the betterment of the organization. These decisions are also taken based on the available market opportunities. If the decisions include strategizing of new market opportunities, they will set the direction of the organization towards new or may be entirely different avenue. This opportunity grabbing process starts the exploration of the market information and experimentation which initiates the innovative processes. This suggests that:

Hypothesis 7: Entrepreneurial leadership style mediates the effect of hierarchical culture on entrepreneurial orientation

The accomplishment of established goals are primary objective of the organizations. In order to achieve the objectives, leadership sometimes extends to external sources for gaining competitive edge in the market (Cameron \& Quinn, 2011). It is the responsibility of the leadership to gain clarity of how the objectives are to be accomplished to maintain the competitive edge in the market (Chen, 2007). This can be considered an innate quality of the leadership to gain an absolute clarity of how the objectives can be met and what level an organization must achieve. The group members are usually unable to visualize the greater perspective of the vision that the leaders have. Therefore, it is the responsibility of the leadership to maintain the external focus by signing contracts with external parties to maintain the competitive edge. This suggests that:

Hypothesis 8: Entrepreneurial leadership style mediates the effect of market culture on entrepreneurial orientation

\section{Research Model and Methodology}

\subsection{Theoretical model}

As entrepreneurial leadership style provides an action-based perspective of the leadership and (Renko et al., 2015) also suggests that entrepreneurial leadership style is aligned towards the leadership which addresses the actions of entrepreneurs and should be tested for organizational context. In this study, role of entrepreneurial leadership style (Renko et al., 2015) has been studied between the organizational cultures proposed by (Cameron and Quinn, 2011) and entrepreneurial orientation (Covin and Slevin, 1989, Engelen et al., 2014). Figure 1 shows the research model which is investigated in the study.

\subsection{Data sampling and procedure}

To study the objective, a cross-sectional study was conducted. The target population for this study were the small and medium sized manufacturing enterprises. The 


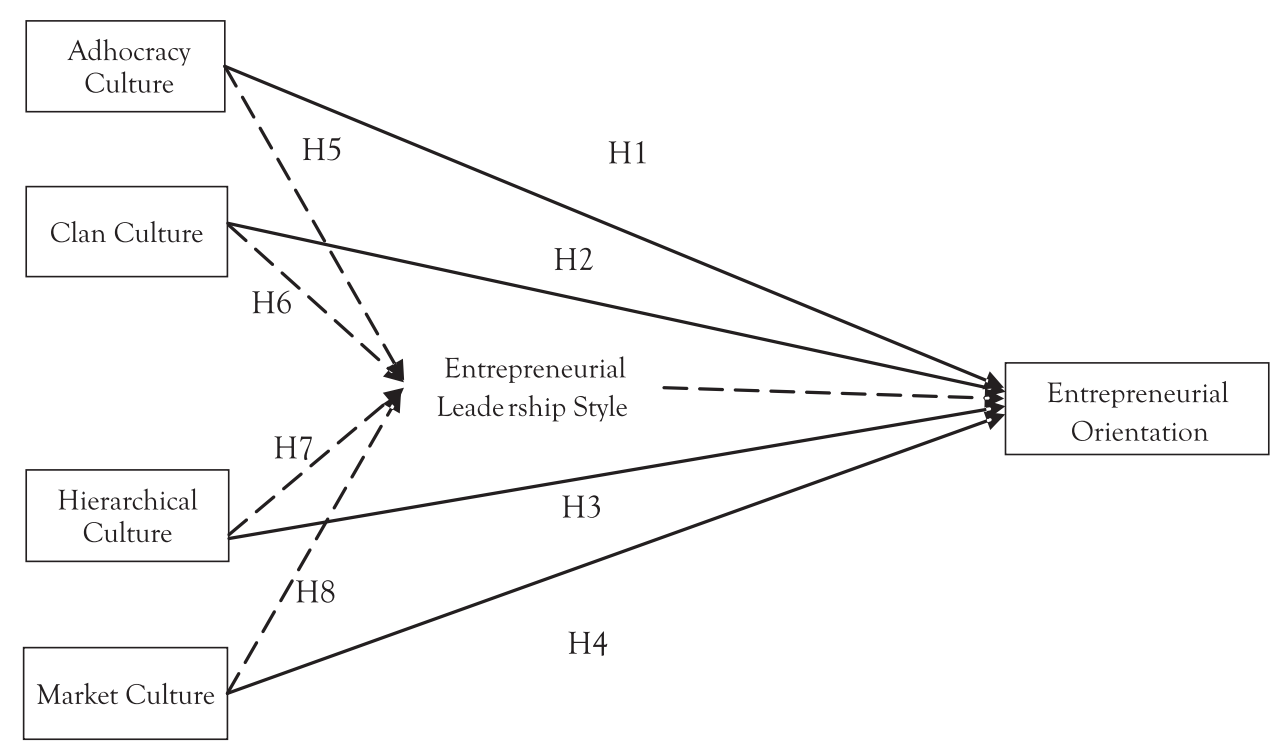

Figure 1: Theoretical Model

firms in Rawalpindi, Islamabad, Lahore, Karachi and Faisalabad were contacted by email requesting for the data collection. As the response of the industries was not encouraging, the firms emailed earlier were contacted by telephone for the permission of data collection. Yet, the response of the industries turned out to be poor. Due to the poor response from the firms, the chambers of commerce of all the five cities were contacted for the help in data collection. Chambers of commerce of two major cities, Rawalpindi and Islamabad responded for the data collection. Chamber of commerce provided their assistance in collection of data after a careful review of the questionnaire. An online questionnaire was then circulated by the chamber of commerce to the small and medium size industries. Total of 215 responses were collected online. 34 responses out of 215 met the outlier criteria and were excluded from the sample. The sample of 181 responses was then analyzed using PLS-SEM (Ringle, Wende, \& Becker, 2015) due to its robustness and greater statistical power (Hair, Ringle, \& Sarstedt, 2011).

\subsection{Measures}

\subsubsection{Organizational culture}

The instrument of organizational culture in Appendix-A was adopted from (Cameron \& Quinn, 2011) which has total of sixteen items. All the items were measured on five-point Likert scale ( 1 = Strongly Disagree ; 5 = Strongly Agree). 


\subsubsection{Entrepreneurial orientation}

The instrument of entrepreneurial orientation in Appendix-A with total of eight items was taken from (Engelen et al., 2014) which is based on (Covin \& Slevin, 1989; George \& Marino, 2011; Miller \& Friesen, 1982). The instrument consisted of three items from risk taking, three items from innovativeness and two items from proactiveness. All the items were measured on five-point Likert scale $(1=$ Strongly Disagree; 5 = Strongly Agree) .

\subsubsection{Entrepreneurial leadership style}

The instrument of entrepreneurial leadership style in Appendix-A was taken from (Renko et al., 2015) which had total of ten items. A five-point Likert Scale was used to measure the responses of entrepreneurial leadership style ( 1 = Strongly Disagree; 5 = Strongly Agree).

\subsection{Demographics}

The unit of analysis were the individuals playing different roles on the various management positions. Total $63 \%$ of the respondents were found out to be males whereas $37 \%$ of the respondents were females. $45.3 \%$ of the respondents had the qualification of undergraduate degree, where $54.1 \%$ of the respondents had graduate degree and only $0.6 \%$ of the respondents had a postgraduate or a doctorate degree. Total of $38.7 \%$ of the data were collected from textile industries, $27.1 \%$ were collected from pharmaceutical industries, $21.5 \%$ of the data was collected from cement industry, $8.8 \%$ were collected from food industries, and 3.9\% were collected from electronics industries. $13.8 \%$ of the respondents were from the small enterprises ranging between 50 to 150 employees per firm whereas $86.2 \%$ of the respondents were from the medium enterprises ranging between 150 to 250 employees per firm (Dar, Ahmed, \& Raziq, 2017).

\section{Analysis}

\subsection{Measurement model}

To assess the internal consistency reliability and convergent validity, Composite Reliability (CR) and AVE were checked. Composite reliability provides internal consistency reliability, where AVE determines positive correlation of the measures of the same construct (Hair Jr, Hult, Ringle, \& Sarstedt, 2016). According to Esposito Vinzi, Chin, Henseler, and Wang (2010) and Hair Jr et al. (2016) the value of the composite reliability should be above 0.7. The results show that Clan Culture (CR $=0.900, A V E$ $=0.750)$, Adhocracy Culture $(C R=0.841, A V E=0.638)$, Hierarchical Culture $(C R$ 
$=0.822, A V E=0.607)$, Market Oriented Culture $(C R=0.789, A V E=0.555)$, Entrepreneurial Orientation $(C R=0.886, A V E=0.721)$ and Entrepreneurial Leadership Style $(C R=0.901, A V E=0.602)$ were found out to be in acceptable range (Hair Jr et al., 2016). According to Hair Jr et al. (2016), the lack of discriminant validity can be observed if the value exceeds 0.9 but more conservative cut-off value of discriminant validity is 0.85 . The results in Table 2 show that the values of all the constructs are below the cut-off values of 0.85 showing a discriminant validity. HTMT inference criterion was also checked and all the values were found out to be below 1 as per the

Table 1: Summary of Outer Loadings of the Construct

\begin{tabular}{|c|c|c|c|c|c|c|}
\hline & $\begin{array}{l}\text { Adhocracy } \\
\text { Culture }\end{array}$ & $\begin{array}{l}\text { Clan Cul- } \\
\text { ture }\end{array}$ & $\begin{array}{l}\text { Entrepre- } \\
\text { neurial Ori- } \\
\text { entation }\end{array}$ & $\begin{array}{l}\text { Hierarchi- } \\
\text { cal Culture }\end{array}$ & $\begin{array}{l}\text { Market } \\
\text { Culture }\end{array}$ & $\begin{array}{c}\text { Entrepre- } \\
\text { neurial } \\
\text { Leadership } \\
\text { Style }\end{array}$ \\
\hline AC1 & 0.798 & & & & & \\
\hline $\mathrm{AC2}$ & 0.801 & & & & & \\
\hline $\mathrm{AC} 3$ & 0.799 & & & & & \\
\hline CC1 & & 0.899 & & & & \\
\hline $\mathrm{CC} 2$ & & 0.872 & & & & \\
\hline $\mathrm{CC} 3$ & & 0.852 & & & & \\
\hline $\mathrm{PA}$ & & & 0.830 & & & \\
\hline RT & & & 0.875 & & & \\
\hline IN & & & 0.841 & & & \\
\hline $\mathrm{HC} 1$ & & & & 0.718 & & \\
\hline $\mathrm{HC} 2$ & & & & 0.834 & & \\
\hline $\mathrm{HC} 3$ & & & & 0.783 & & \\
\hline $\mathrm{MC2}$ & & & & & 0.767 & \\
\hline MC3 & & & & & 0.745 & \\
\hline MC4 & & & & & 0.713 & \\
\hline EL2 & & & & & & 0.765 \\
\hline EL3 & & & & & & 0.738 \\
\hline EL6 & & & & & & 0.862 \\
\hline EL8 & & & & & & 0.758 \\
\hline EL9 & & & & & & 0.758 \\
\hline EL10 & & & & & & 0.804 \\
\hline
\end{tabular}

$\mathrm{AC}=$ Adhocracy Culture, $\mathrm{CC}=$ Clan Culture $\mathrm{HC}=$ Hierarchical Culture, $\mathrm{MC}=$ Market Culture, $\mathrm{EL}=$ Entrepreneurial Leadership Style, $\mathrm{PA}=$ Proactiveness, $\mathrm{RT}=$ Risk Taking, $\mathrm{IN}=$ Innovativeness 
suggestion of (Henseler, 2010). This also shows that the constructs are empirically distinct from each other.

To achieve the convergent and discriminant validity, outer loadings of the construct were checked for any loading below 0.7. As per the recommendations of (Hair Jr et al., 2016), any loading with the value less than 0.7 was deleted such that the composite reliability is not affected by the deletion of the item. One item from Adhocracy culture, one item from Clan Culture, one item from hierarchical culture, three items from entrepreneurial leadership style were deleted because their loading was less than 0.7 and after deletion of these items the composite reliability either had increased or had no effect. One item from the Market culture was also deleted because

Table 2: Heterotrait-Monotrait Ratio (HTMT)

\begin{tabular}{|c|c|c|c|c|c|c|}
\hline & 1 & 2 & 3 & 4 & 5 & 6 \\
\hline \multicolumn{7}{|l|}{$\begin{array}{c}\text { Adhocracy } \\
\text { Culture }\end{array}$} \\
\hline $\begin{array}{c}\text { Clan Cul- } \\
\text { ture }\end{array}$ & 0.764 & & & & & \\
\hline $\begin{array}{l}\text { Entrepre- } \\
\text { neurial } \\
\text { Leadership } \\
\text { Style }\end{array}$ & 0.846 & 0.821 & & & & \\
\hline $\begin{array}{c}\text { Entrepre- } \\
\text { neurial } \\
\text { Orientation }\end{array}$ & 0.637 & 0.593 & 0.798 & & & \\
\hline $\begin{array}{c}\text { Hierarchical } \\
\text { Culture }\end{array}$ & 0.715 & 0.653 & 0.712 & 0.652 & & \\
\hline $\begin{array}{l}\text { Market } \\
\text { Culture }\end{array}$ & 0.683 & 0.562 & 0.633 & 0.739 & 0.620 & \\
\hline
\end{tabular}

the average variance extracted (AVE) was below 0.5. After the deletion of one item from Market culture the AVE was found out to be in acceptable range as suggested by (Hair Jr et al., 2016). The final construct and its loading can be seen in Table 1 .

\subsection{Structural model:}

The direct relationship between the organizational cultures and entrepreneurial orientation in Table 3 shows that the adhocracy culture has no significant relationship with the entrepreneurial orientation with ( $p$-value $=0.808 ;$ tvalue $=0.243 ; \beta=-0.022$ ) rejecting Hypothesis 1. Similarly, clan culture with the (p-value $=0.799$; tvalue $=0.255$; 
$\beta=-0.021$ ) shows that clan culture has an insignificant relationship with the entrepreneurial orientation rejecting Hypothesis 2. However, hierarchical culture with (p-value

Table 3: Direct Effect and Significance

\begin{tabular}{|c|c|c|}
\hline Direct Relationships & T Statistics & Significance \\
\hline AC $>$ EO & 0.243 & 0.808 \\
\hline CC $>$ EO & 0.255 & 0.799 \\
\hline HC $>$ EO & 2.007 & 0.045 \\
\hline MC $>$ EO & 4.652 & 0.000 \\
\hline
\end{tabular}

$\mathrm{AC}=$ Adhocracy Culture, $\mathrm{CC}=$ Clan Culture, $\mathrm{HC}=$ Hierarchical Culture, $\mathrm{MC}=$ Market Culture, $\mathrm{EO}=$ Entrepreneurial Orientation

$=0.045 ;$ tvalue $=2.007 ; \beta=0.140$ ) shows that hierarchical culture has a significant relationship with entrepreneurial orientation rejecting Hypothesis 3. Market culture on the other hand has a significant relationship ( $p$-value $=0.000 ;$ tvalue $=4.652 ; \beta$ $=0.255$ ) with entrepreneurial orientation accepting Hypothesis 4 .

According to Baron and Kenny (1986), the direct relationship must exist in order to proceed for mediation. However, later studies show indirect effect can be studied even if there is no relationship between exogenous and endogenous variable (Hayes, 2009; Zhao et al., 2010). As adhocracy culture and clan culture are insignificant in Table 3, entrepreneurial leadership style was mediated in the model and tested for the rest of the hypotheses. The results in Table 4 show the relationship of all the organizational cultures with entrepreneurial leadership style was found out to be significant with adhocracy culture $(\mathrm{p}=0.000 ; \mathrm{t}$-value $=4.624 ; \beta=0.300)$, clan culture to be $(\mathrm{p}=$ $0.000 ; \mathrm{t}$-value $=5.082 ; \beta=0.395)$ and hierarchical culture to be $(\mathrm{p}=0.010 ; \mathrm{t}$-value $=2.577 ; \beta=0.158)$, where market culture was found out to be insignificant with ( $\mathrm{p}$ $=0.069 ; \mathrm{t}$-value $=1.822 ; \beta=0.110$ ). The mediation of entrepreneurial leadership style shows that indirect effect ( 0.151$)$ of adhocracy culture on entrepreneurial orientation was found out to be significant with $(\mathrm{p}=0.001 ; \mathrm{t}$-value $=3.491)$. Clan culture has significant indirect effect (0.199) on entrepreneurial orientation with $(p=0.000$ ; t-value $=3.792)$ and hierarchical culture has an indirect relationship of $(0.080)$ on entrepreneurial orientation with $(\mathrm{p}=0.024$; $\mathrm{t}$-value $=2.257)$. However, market culture which was significant in direct relationship has insignificant indirect effect $(0.055)$ on entrepreneurial orientation with $(\mathrm{p}=0.092 ; \mathrm{t}$-value $=1.686)$. The relationship of entrepreneurial leadership style on entrepreneurial orientation is also highly significant at $(\mathrm{p}=0.000 ; \mathrm{t}$-value $=6.068 ; \square=0.503)$. Results obtained from the mediation of entrepreneurial leadership style accepts the Hypothesis 5 and Hypothesis 6 and Hypothesis 7. However, the mediation of entrepreneurial leadership style between the market culture and entrepreneurial orientation rejects the Hypothesis 8 based 
Table 4: Indirect Effect and Significance

\begin{tabular}{|c|c|c|}
\hline Indirect Relationships & T Statistics & Significance \\
\hline AC $>$ EL $>$ EO & 3.491 & 0.001 \\
\hline CC $>$ EL $>$ EO & 3.792 & 0.000 \\
\hline HC $>$ EL $>$ EO & 2.257 & 0.024 \\
\hline MC $>$ EL $>$ EO & 1.686 & 0.092 \\
\hline
\end{tabular}

$\mathrm{AC}=$ Adhocracy Culture, $\mathrm{CC}=$ Clan Culture, $\mathrm{HC}=$ Hierarchical Culture, $\mathrm{MC}=$ Market Culture, $\mathrm{EO}=$ Entrepreneurial Orientation, $\mathrm{EL}=$ Entrepreneurial Leadership Style

on the insignificance of indirect relationship. The results show complete indirect relationship of entrepreneurial leadership style between adhocracy culture and entrepreneurial orientation and clan culture and entrepreneurial orientation, whereas partial mediation in case of hierarchical culture (Carrión, Nitzl, \& Roldán, 2017).

The overall effect of four organizational cultures was also evaluated by $R^{2}, f^{2}$ and $Q^{2} . R^{2}$ explains the overall variance in the endogenous variable due to exogenous variables, $f^{2}$ evaluates the effect size of exogenous variable on endogenous variable and $Q^{2}$ explains the contribution of exogenous variable's contribution on endogenous variable. The overall effect of exogenous variables on mediator entrepreneurial leadership style was found out to be $\left(R^{2}=0.618, R_{\text {adjusted }}^{2}=0.609\right)$ and on endogenous variable entrepreneurial orientation was found out to be $\left(R^{2}=0.524, R 2_{\text {adjusted }} 0.511\right)$. As per the cut-off value of $R^{2}=0.5$ recommended by (Hair Jr et al., 2016), the overall medium variance was explained in mediator entrepreneurial leadership style and endogenous variable entrepreneurial orientation by the four organizational cultures. According to cut-off thresholds defined by Hair Jr et al. (2016), the results show that adhocracy culture has no effect on entrepreneurial orientation with the value of $f^{2}=$ 0.000 , however, adhocracy culture has a almost a medium effect on entrepreneurial leadership style with the value of $f^{2}=0.130$. Clan culture has no effect on entrepreneurial orientation with the value of $f^{2}=0.000$ whereas clan culture has a large effect on entrepreneurial leadership style with the value of $f^{2}=0.233$. Entrepreneurial leadership style has large effect on entrepreneurial orientation with value of $f^{2}=0.203$. Hierarchical culture has an effect of $f^{2}=0.025$ on entrepreneurial orientation which is a low effect and the effect of hierarchical culture on entrepreneurial leadership style is small as well with $f^{2}=0.042$. The effect of market culture on entrepreneurial orientation is small with the value of $f^{2}=0.098$ and effect of market culture on entrepreneurial leadership style is also small with $f^{2}=0.023$. The value of $Q^{2}=0.343$ between exogenous variables and mediator entrepreneurial leadership style suggests large predictive relevance and the value of $Q^{2}=0.334$ between exogenous variables and endogenous variable entrepreneurial leadership style also suggests large predictive 


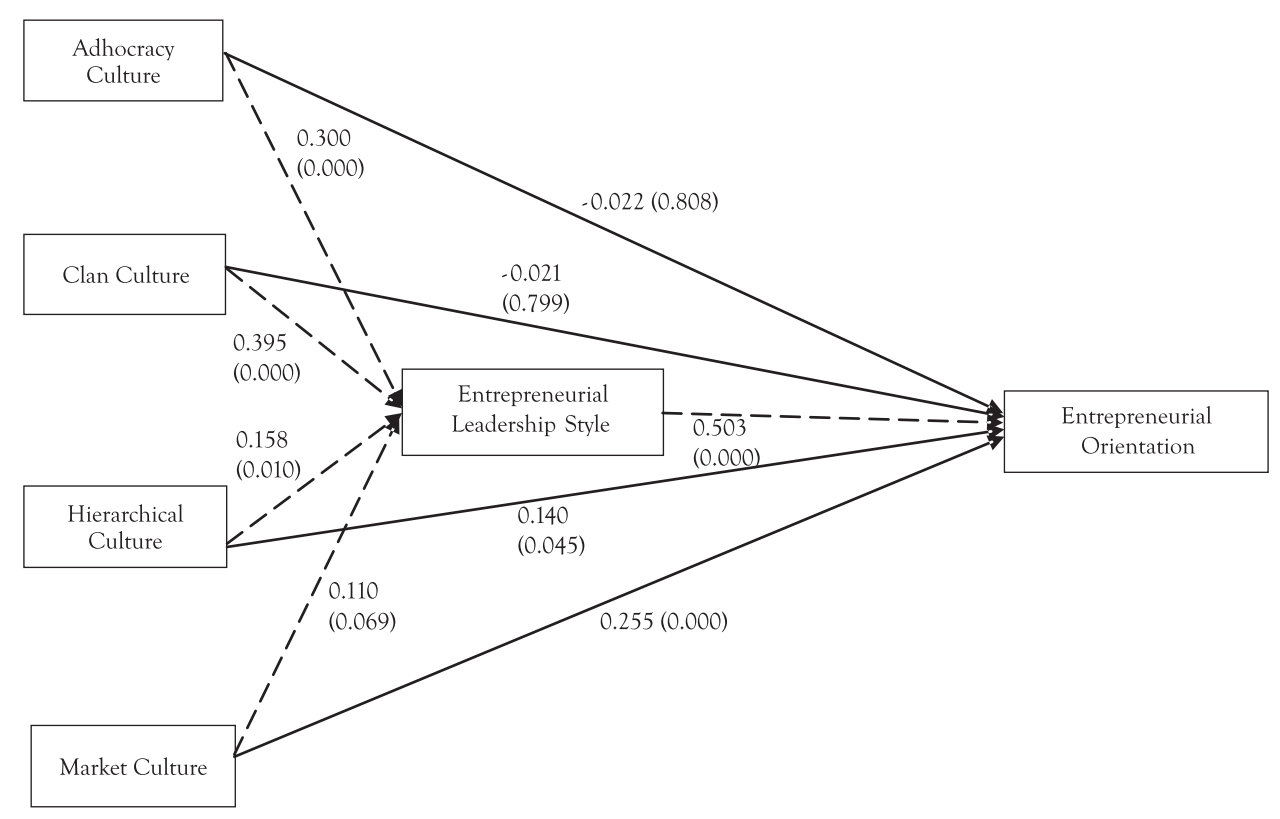

Figure 2: Measurement Model

relevance (Hair Jr et al., 2016).

There is a substantial difference in the relationships between organizational culture and entrepreneurial orientation in the absence and presence of entrepreneurial leadership style. The organizational cultures like adhocracy culture prove to be significant only when the entrepreneurial leadership style mediates between the relationship of organizational culture and entrepreneurial orientation suggesting an indirect relationship. Unlike the description of (Cameron \& Quinn, 2011; Naranjo-Valencia, Jiménez-Jiménez, \& Sanz-Valle, 2011), the adhocracy culture directly, did not prove to be significant for entrepreneurial orientation whereas adhocracy culture is expected to encourage the development of new and innovative products/ services. The hypothesized relationship between adhocracy culture was only indirectly significant with entrepreneurial leadership style in between. This means that it is the entrepreneurial leadership style which enables the entrepreneurial process in the organization and tends to lead the group members towards the opportunity identification. This also suggests that it is the entrepreneurial leadership style only, which is responsible for the identification of any opportunity in the market. The hypothesized relationship of entrepreneurial leadership style as a mediator, failed to provide any significant relationship with market culture, which suggests lack of external focus. Zaheer, ur Rehman, and Ahmad (2006) identified market culture as one of the preferred organizational cultures in small and medium size industries in 
Pakistan. In this study as well, the market culture remains significant without entrepreneurial leadership style. This shows that leadership in the firms do not think that conducting of any exchanges such as contracts with other constituencies, for example firms or businesses of their own sort may tend to influence the entrepreneurial orientation. Significant relationship with hierarchical culture shows that firms are focused internally. Although internal focus has previously been studied to have a negative relationship with entrepreneurial orientation (Brettel, Chomik, \& Flatten, 2015). According to Cameron and Quinn (2011), the behaviors such as high information flow through the system by maintaining a manager in-charge of the system can be adopted to bring the hierarchical system. The action like flow of information has previously been studied to be important for knowledge accumulation (Al-Hawamdeh, 2002), which is important for entrepreneurial orientation (Bojica, del Mar Fuentes, \& Gómez-Gras, 2011; De Clercq, Dimov, \& Thongpapanl, 2013). This is not the only study which shows that organizations have high level of control in the organization. A study carried out in Libya (Zahari \& Shurbagi, 2012) also shows that the hierarchical culture was dominant in their National Oil Corporation. Similarly, the studies carried out in Pakistan also show high internal focus (Masood, Dani, Burns, \& Backhouse, 2006; Paracha, Qamar, Mirza, Hassan, \& Waqas, 2012; Rafiq Awan $\&$ Mahmood, 2010). Entrepreneurial leadership style also plays an important role in mentoring and supporting the group members of the organization to work on the predefined objectives that the leadership has already set for them.

\section{Conclusion}

The study concludes that the leadership in the small and medium sized firms in Pakistan tend to operate with high level of internal focus and high control in the presence of leadership. The study also reveals that it is the leadership which is responsible for opportunity identification for the new avenues of business and the leadership supports and acts as a mentor for the group members working in the firm. However, the leadership also tends to operate the firms and businesses in confined boundaries and do not allow any external affiliation with any other firm or business. This behavior of the top tier of the firms may not allow the business to grow any further from a certain limit while providing the limited benefit to the owners of the firm or the business. Supervisors, managers and owners of the small and medium sized firms need to adopt the entrepreneurial leadership style for better strategic orientation and growth.

\section{Implications}

The findings of this study have high implications on the practitioners such as supervisors, managers and owners in small and medium size industry of Pakistan, 
especially industries studied in this study. The study will help top tier of the firms in these industries to understand the importance of role of entrepreneurial leadership style in different types of organizational cultures. As entrepreneurial leadership tends to provide action-based perspective of the leadership, the practitioners will be able to evaluate what actions are to be taken to enhance the overall entrepreneurial orientation. Not only that, the findings of the study will help the leaders to understand the deficiencies in their organizational structure and develop solution for better competitive edge in the market. As findings of the study show high level of internal focus and low level of external focus in the firms of these industries. The study will help the leaders of these industries to concentrate more on the external focus towards the market for two reasons. First, it will help in collaboration with the other similar firms in the market and second, it will help the firms to look into the external market requirements. Both actions will help the firms to gain the competitive edge and growth in the market. Similarly, the findings also advocate entrepreneurial leadership style to be necessary for supportive culture and innovative culture in the firms. The supervisors, managers and owners of the firms can adopt the entrepreneurial leadership style so that the culture with supportive behavior and mentorship to create innovative solutions can effectively enhance entrepreneurial orientation. The findings of this study contribute contextually as well as empirically in existing body of knowledge. This contribution of knowledge will help the researchers further to evaluate entrepreneurial leadership style with other leadership perspectives such as leadership traits, behaviors and styles.

\section{Limitation and Future Work}

One of the limitations of the study was the data collection. It was difficult to collect the data directly from the firms or businesses. The firms or businesses either refused directly for the data collection, or they never responded. This caused the delay in the data collection. This is the reason the Chamber of Commerce were requested for the help. Even in the presence of the Chamber of Commerce, the direct contact with the firms or businesses could not be made. More data could have been collected if the firms and industries had an open access for the researchers. As the focus of the study was to investigate the role of entrepreneurial leadership, other leadership perspectives could have been added in the existing study for more in-depth view. Moreover, small and medium size industries, having inadequate resources need to focus on the development of social capital. One of the limitations of this study was the involvement of social capital in small and medium size industry.

This study can further be extended to study different types of leadership affecting the entrepreneurial orientation in these organizational cultures. Specially, higher 
internal focus in the organizations suggests that comparative analysis of leadership theories such as leader member exchange, transformational leadership, participative leadership and directive leadership should be studied. Further, the industry specific studies can also be carried out and then compared. This type of study can prove to be very beneficial in identifying the organizational and leadership problems and suggesting the solutions to address these problems. Also, role of leadership can also be studied for the relationship between the organizational culture and firm performance. As the study also reveals a higher level of internal control, leadership's role for employee satisfaction can also be studied in future.

\section{References}

Al-Hawamdeh, S. (2002). Knowledge management: Re-thinking information management and facing the challenge of managing tacit knowledge. Information research, 8(1), 8-1.

Amer, H. (2017). Impact of leadership styles on entrepreneurs' business success. (Doctor of Philosophy (PhD)), Old Dominion University, Stemps Theses \& Disserations. Retrieved from https://digitalcommons. odu.edu/cgi/viewcontent.cgi?article=1022\& context=stemps_etds

Anderson, B. S., Kreiser, P. M., Kuratko, D. F., Hornsby, J. S., \& Eshima, Y. (2015). Reconceptualizing entrepreneurial orientation. Strategic Management Journal, 36(10), 1579-1596.

Atuahene』Gima, K., Slater, S. F., \& Olson, E. M. (2005). The contingent value of responsive and proactive market orientations for new product program performance. Journal of product innovation management, 22(6), 464-482.

Barney, J. (1991). Firm resources and sustained competitive advantage. Journal of Management, 17(1), 99-120.

Barney, J., \& Zajac, E. J. (1994). Competative organizational behavior: Toward an organizationally-based theory of competitive advantage. Strategic Management Journal, 15(1994), 5-9.

Barney, J. B. (1986). Organizational culture: Can it be a source of sustained competitive advantage? Academy of management Review, 11(3), 656-665.

Baron, R. M., \& Kenny, D. A. (1986). The moderator-mediator variable distinction in social psychological research: Conceptual, strategic, and statistical considerations. Journal of Personality and Social Psychology, 51(6), 1173.

Baum, J. R., \& Locke, E. A. (2004). The relationship of entrepreneurial traits, skill, and motivation to subsequent venture growth. Journal of Applied Psychology, 89(4), 587-598. doi: 10.1037/00219010.89.4.587

Berson, Y., Oreg, S., \& Dvir, T. (2008). CEO values, organizational culture and firm outcomes. Journal of Organizational Behavior, 29(5), 615-633. 
Bojica, A. M., del Mar Fuentes, M., \& Gómez-Gras, J. M. (2011). Radical and incremental entrepreneurial orientation: The effect of knowledge acquisition. Journal of Management $\mathcal{G}$ Organization, 17(3), 326-343.

Brettel, M., Chomik, C., \& Flatten, T. C. (2015). How organizational culture influences innovativeness, proactiveness, and riskltaking: Fostering entrepreneurial orientation in SMEs. Journal of Small Business Management, 53(4), 868-885.

Brouthers, K. D., Nakos, G., \& Dimitratos, P. (2015). SME entrepreneurial orientation, international performance, and the moderating role of strategic alliances. Entrepreneurship Theory and Practice, 39(5), 1161-1187.

Cameron, K. S. (1985). Cultural congruence, strength, and type: relationships to effectiveness. Working Paper, Graduate School of Business Administration, University of Michigan.

Cameron, K. S., \& Quinn, R. E. (2011). Diagnosing and changing organizational culture: Based on the competing values framework: John Wiley \& Sons.

Carrión, G. C., Nitzl, C., \& Roldán, J. L. (2017). Mediation analyses in partial least squares structural equation modeling: guidelines and empirical examples. In Partial Least Squares Path Modeling (pp. 173-195): Springer.

Chen, M. H. (2007). Entrepreneurial leadership and new ventures: Creativity in entrepreneurial teams. Creativity and Innovation Management, 16(3), 239-249.

Chung-Wen, Y. (2008). The relationships among leadership styles, entrepreneurial orientation, and business performance. Managing Global Transitions, 6(3), 257-275.

Cogliser, C. C., \& Brigham, K. H. (2004). The intersection of leadership and entrepreneurship: Mutual lessons to be learned. The Leadership Quarterly, 15(6), 771-799.

Covin, J. G., \& Slevin, D. P. (1989). Strategic management of small firms in hostile and benign environments. Strategic Management Journal, 10(1), 75-87.

Crant, J. M. (1996). The proactive personality scale as a predictor of entrepreneurial intentions. Journal of Small Business Management, 34, 42-49.

Cunningham, J. B., \& Lischeron, J. (1991). Defining entrepreneurship. Journal of Small Business Management, 29(1), 45-61.

Dar, M. S., Ahmed, S., \& Raziq, A. (2017). Small and medium-size enterprises in Pakistan: Definition and critical issues. Pakistan Business Review, 19(1), 46-70.

De Clercq, D., Dimov, D., \& Thongpapanl, N. (2013). Organizational social capital, formalization, and internal knowledge sharing in entrepreneurial orientation formation. Entrepreneurship Theory and Practice, 37(3), 505-537.

De Hoogh, A. H. B., Greer, L. L., \& Den Hartog, D. N. (2015). Diabolical dictators or capable com- 
manders? An investigation of the differential effects of autocratic leadership on team performance. The Leadership Quarterly, 26(5), 687-701.

de Vries, R. E., Roe, R. A., \& Taillieu, T. C. (2002). Need for leadership as a moderator of the relationships between leadership and individual outcomes. The Leadership Quarterly, 13(2), 121-137.

Denison, D. R. (1996). What is the difference between organizational culture and organizational climate? A native's point of view on a decade of paradigm wars. Academy of management Review, 21(3), 619-654.

Dinh, J. E., Lord, R. G., Gardner, W. L., Meuser, J. D., Liden, R. C., \& Hu, J. (2014). Leadership theory and research in the new millennium: Current theoretical trends and changing perspectives. The Leadership Quarterly, 25(1), 36-62.

Dooley, K. J. (1997). A complex adaptive systems model of organization change. Nonlinear dynamics, psychology, and life sciences, 1(1), 69-97.

Engelen, A., Flatten, T. C., Thalmann, J., \& Brettel, M. (2014). The effect of organizational culture on entrepreneurial orientation: A comparison between Germany and Thailand. Journal of Small Business Management, 52(4), 732-752. doi: 10.1111/jsbm.12052

Engelen, A., Gupta, V., Strenger, L., \& Brettel, M. (2015). Entrepreneurial orientation, firm performance, and the moderating role of transformational leadership behaviors. Journal of Management, 41(4), 1069-1097. doi: 10.1177/0149206312455244

Ensley, M. D., Hmieleski, K. M., \& Pearce, C. L. (2006). The importance of vertical and shared leadership within new venture top management teams: Implications for the performance of startups. The Leadership Quarterly, 17(3), 217-231. doi: 10.1016/j.leaqua.2006.02.002

Esposito Vinzi, V., Chin, W. W., Henseler, J., \& Wang, H. (2010). Handbook of partial least squares: Concepts, methods and applications: Heidelberg, Dordrecht, London, New York: Springer.

Fernald, L. W., Solomon, G. T., \& Tarabishy, A. (2005). A new paradigm: Entrepreneurial leadership. Southern business review, 30(2), 1-10.

Floyd, S. W., \& Wooldridge, B. (1999). Knowledge creation and social networks in corporate entrepreneurship: The renewal of organizational capability. Entrepreneurship Theory and Practice, 23(3), 123-144.

Forlani, D., \& Mullins, J. W. (2000). Perceived risks and choices in entrepreneurs' new venture decisions. Journal of Business Venturing, 15(4), 305-322. doi: 10.1016/S0883-9026(98)00017-2

Friesenbichler, K., \& Selenko, E. (2017). Firm performance in challenging business climates: Does managerial work engagement make a difference? Asian Business $\mathcal{E}$ Management, 16(1-2), 25-49.

George, B. A., \& Marino, L. (2011). The epistemology of entrepreneurial orientation: Conceptual formation, modeling, and operationalization. Entrepreneurship Theory and Practice, 35(5), 989-1024.

Gupta, V., MacMillan, I. C., \& Surie, G. (2004). Entrepreneurial leadership: Developing and measuring a cross-cultural construct. Journal of Business Venturing, 19(2), 241-260. 
Hair, J. F., Ringle, C. M., \& Sarstedt, M. (2011). PLS-SEM: Indeed a silver bullet. Journal of Marketing theory and Practice, 19(2), 139-152.

Hair Jr, J. F., Hult, G. T. M., Ringle, C., \& Sarstedt, M. (2016). A primer on partial least squares structural equation modeling (PLS-SEM): Sage Publications.

Harrison, R., Leitch, C., \& McAdam, M. (2015). Breaking glass: Toward a gendered analysis of entrepreneurial leadership. Journal of Small Business Management, 53(3), 693-713.

Hayes, A. F. (2009). Beyond Baron and Kenny: Statistical mediation analysis in the new millennium. Communication monographs, 76(4), 408-420.

Hazy, J. K., \& Uhl-Bien, M. (2015). Towards operationalizing complexity leadership: How generative, administrative and community-building leadership practices enact organizational outcomes. Leadership, 11(1), 79-104.

Henseler, J. (2010). Covariance-based Structural Equation Modeling : Foundations and Applications.

Hodson, R. (1991). The active worker: compliance and autonomy at the workplace. Journal of Contemporary Ethnography, 20(1), 47-78. doi: 0803973233

Holland, D. V., \& Shepherd, D. A. (2013). Deciding to persist: Adversity, values, and entrepreneurs' decision policies. Entrepreneurship Theory and Practice, 37(2), 331-358.

Hopkins, M. M., Tidd, J., Nightingale, P., \& Miller, R. (2011). Generative and degenerative interactions: positive and negative dynamics of open, user-centric innovation in technology and engineering consultancies. REd Management, 41(1), 44-60.

Hu, H., Gu, Q., \& Chen, J. (2013). How and when does transformational leadership affect organizational creativity and innovation? Critical review and future directions. Nankai Business Review International, 4(2), 147-166.

Huey Yiing, L., \& Zaman Bin Ahmad, K. (2009). The moderating effects of organizational culture on the relationships between leadership behaviour and organizational commitment and between organizational commitment and job satisfaction and performance. Leadership $\mathcal{E}$ Organization Development Journal, 30(1), 53-86.

Hughes, M., \& Morgan, R. E. (2007). Deconstructing the relationship between entrepreneurial orientation and business performance at the embryonic stage of firm growth. Industrial Marketing Management, 36(5), 651-661. doi: 10.1016/j.indmarman.2006.04.003

Ireland, R. D., Hitt, M. A., \& Sirmon, D. G. (2003). A model of strategic entrepreneurship: The construct and its dimensions. Journal of Management, 29(6), 963-989.

James, L. R., Choi, C. C., Ko, C.-H. E., McNeil, P. K., Minton, M. K., Wright, M. A., \& Kim, K.-i. (2008). Organizational and psychological climate: A review of theory and research. European Journal of Work and Organizational Psychology, 17(1), 5-32. 
Jensen, S. M., \& Luthans, F. (2006). Entrepreneurs as authentic leaders: Impact on employees' attitudes. Leadership E Organization Development Journal, 27(8), 646-666. doi: 10.1108/01437730610709273

Jia, J., Yan, J., Cai, Y., \& Liu, Y. (2018). Paradoxical leadership incongruence and Chinese individuals' followership behaviors: moderation effects of hierarchical culture and perceived strength of human resource management system. Asian Business $\mathcal{E}$ Management, 17(5), 313-338.

Kan, K., \& Tsai, W.-D. (2006). Entrepreneurship and risk aversion. Small Business Economics, 26(5), 465-474.

Kreiser, P. M. (2011). Entrepreneurial orientation and organizational learning: The impact of network range and network closure. Entrepreneurship: Theory and Practice, 35(5), 1025-1050. doi: 10.1111/j.1540-6520.2011.00449.x

Kuratko, D. F. (2007). Entrepreneurial leadership in the 21st century: Guest editor's perspective. Journal of Leadership $\mathbb{E}$ Organizational Studies, 13(4), 1-11.

Lakomski, G. (2001). Organizational change, leadership and learning: Culture as cognitive process. International Journal of Educational Management, 15(2), 68-77.

Lawrence, K. a., Street, T., Quinn, R. E., \& Peter, L. (2009). Behavioral complexity in leadership: The psychometric properties of a new instrument. The Leadership Quarterly, 20(2), 87-102. doi: 10.1016/j. leaqua.2009.01.014

Leitch, C. M., \& Volery, T. (2017). Entrepreneurial leadership: Insights and directions. International Small Business Journal, 35(2), 147-156.

Leyerer, P. S. (2012). The role of organizational culture in developing an entrepreneurial oriented company. (Master Corporate Entrepreneurship and Innovation), Lund University. Retrieved from http://lup.lub. lu.se/luur/download? func $=$ downloadFile\& recordOId=2620072\& fileOId $=2620079$

Lumpkin, G. T., \& Dess, G. G. (2001). Linking two dimensions of entrepreneurial orientation to firm performance: The moderating role of environment and industry life cycle. Journal of Business Venturing, 16(5), 429-451. doi: 10.1016/S0883-9026(00)00048-3

Macko, A., \& Tyszka, T. (2009). Entrepreneurship and risk taking. Applied psychology, 58(3), 469-487.

Malby, B. (2006). How does leadership make a difference to organizational culture and effectiveness. Northern Leadership Academy.

Masood, S. A., Dani, S., Burns, N. D., \& Backhouse, C. (2006). Transformational leadership and organizational culture: the situational strength perspective. Proceedings of the Institution of Mechanical Engineers, Part B: Journal of Engineering Manufacture, 220(6), 941-949.

McMullen, J. S., Plummer, L. a., \& Acs, Z. J. (2007). What is an entrepreneurial opportunity? Small Business Economics, 28(4), 273-283. doi: 10.1007/s11187-006-9040-z

Miao, Q., Eva, N., Newman, A., \& Cooper, B. (2017). CEO entrepreneurial leadership and performance 
outcomes of top management teams in entrepreneurial ventures: The mediating effects of psychological safety. Journal of Small Business Management.

Michael, S., Storey, D., \& Thomas, H. (2002). Discovery and coordination in strategic management and entrepreneurship. Strategic entrepreneurship: Creating a new mindset, 45-65.

Miller, D. (1983). The correlates of entrepreneurship in three types of firms. Management Science, 29(7), 770-791.

Miller, D., \& Friesen, P. H. (1982). Innovation in conservative and entrepreneurial firms: Two models of strategic momentum. Strategic Management Journal, 3(1), 1-25.

Morrison, A. (2007). Entrepreneurs or intrapreneurs? (pp. 86-109): Routledge.

Nanjundeswaraswamy, T. S., \& Swamy, D. R. (2014). Leadership styles. Advances in management, 7(2), 57-57.

Naranjo-Valencia, J. C., Jiménez-Jiménez, D., \& Sanz-Valle, R. (2011). Innovation or imitation? The role of organizational culture. Management Decision, 49(1), 55-72.

Nicholson, N. (1998). Personality and entrepreneurial leadership: A study of the heads of the UK's most successful independent companies. European Management Journal, 16(5), 529-539.

Norton, W. I., \& Moore, W. T. (2006). The influence of entrepreneurial risk assessment on venture launch or growth decisions. Small Business Economics, 26(3), 215-226. doi: 10.1007/s11187-004-5612-y

Ogbonna, E., \& Harris, L. C. (2000). Leadership style, organizational culture and performance: empirical evidence from UK companies. International Journal of Human Resource Management, 11(4), 766-788.

Paracha, M. U., Qamar, A., Mirza, A., Hassan, I., \& Waqas, H. (2012). Impact of leadership style (transformational \& transactional leadership) on employee performance \& mediating role of job satisfaction. Study of private school (Educator) in Pakistan. Global Journal of Management and Business Research, 12(4), 55-64.

Pérez-Luño, A., Wiklund, J., \& Cabrera, R. V. (2011). The dual nature of innovative activity: How entrepreneurial orientation influences innovation generation and adoption. Journal of Business Venturing, 26(5), 555-571. doi: 10.1016/j.jbusvent.2010.03.001

Pourmohammad, S., \& Rezai, B. (2016). Determining the relationship between autocratic leadership and innovation in the telecommunication company of kermanshah city. International Journal of Management, Accounting $\mathcal{E}$ Economics, 2(2), 17-24.

Rafiq Awan, M., \& Mahmood, K. (2010). Relationship among leadership style, organizational culture and employee commitment in university libraries. Library management, 31(4/5), 253-266.

Rahim, A. W. P. A., Ismail, W. K. W., Thurasamy, R., \& Abd, I. (2018). The relationship of individual creativity with entrepreneurial intention via individual entrepreneurial orientation (IEO). International Journal of Innovation and Business Strategy, 9(1), 41-54. 
Renko, M., El Tarabishy, A., Carsrud, A. L., \& Brännback, M. (2015). Understanding and measuring entrepreneurial leadership style. Journal of Small Business Management, 53(1), 54-74. doi: 10.1111/ jsbm.12086

Ringle, C. M., Wende, S., \& Becker, J.-M. (2015). SmartPLS 3. SmartPLS GmbH: Boenningstedt.

Sarasvathy, S. D., Dew, N., Velamuri, S. R., \& Venkataraman, S. (2003). Three views of entrepreneurial opportunity. Handbook of entrepreneurship research (pp. 141-160): Springer.

Sarros, J. C., Cooper, B. K., \& Santora, J. C. (2008). Building a climate for innovation through transformational leadership and organizational culture. Journal of Leadership $\mathcal{E}$ Organizational Studies, 15(2), 145-158. doi: 10.1177/1548051808324100

Semrau, T., Ambos, T., \& Kraus, S. (2016). Entrepreneurial orientation and SME performance across societal cultures: An international study. Journal of Business Research, 69(5), 1928-1932.

Sklaveniti, C. (2017). Processes of entrepreneurial leadership: Co-acting creativity and direction in the emergence of new SME ventures. International Small Business Journal, 35(2), 197-213.

Somech, A. (2005). Directive versus participative leadership: Two complementary approaches to managing school effectiveness. Educational Administration Quarterly, 41(5), 777-800.

Stevenson, H. H., \& Jarillo, J. C. (1990). A paradigm of entrepreneurship: Entrepreneurial management. Strategic Management Journal, 11(5), 17-27.

Su, Z., Xie, E., \& Li, Y. (2011). Entrepreneurial orientation and firm performance in new ventures and established firms. Journal of Small Business Management, 49(22), 558-577. doi: 10.1111/j.1540627X.2011.00336.x

Surie, G., \& Ashley, A. (2008). Integrating pragmatism and ethics in entrepreneurial leadership for sustainable value creation. Journal of Business Ethics, 81(1), 235-246.

Surie, G., \& Hazy, J. K. (2006). Generative leadership: Nurturing innovation in complex systems. Emergence: Complexity $\mathcal{E}$ Organization, 8(4), 13-26.

Tong, Y. K. A. R. D. (2015). Managing complexity via the competing values framework. Journal of Management Development, 34(6), 635-673.

Trice, H. M., \& Beyer, J. M. (1993). The cultures of work organizations: Prentice-Hall, Inc.

Tse, H. H. M., Huang, X., \& Lam, W. (2013). Why does transformational leadership matter for employee turnover? A multi-foci social exchange perspective. Leadership Quarterly, 24(5), 763-776. doi: 10.1016/j.leaqua.2013.07.005

Wallace, J., Hunt, J., \& Richards, C. (1999). The relationship between organisational culture, organisational climate and managerial values. International Journal of Public Sector Management, 12(7), 548-564. doi: 10.1108/09513559910305339 
Wang, C. J., Tsai, H. T., \& Tsai, M. T. (2014). Linking transformational leadership and employee creativity in the hospitality industry: The influences of creative role identity, creative self-efficacy, and job complexity. Tourism Management, 40, 79-89. doi: 10.1016/j.tourman.2013.05.008

Wayne, S. J., Shore, L. M., \& Liden, R. C. (1997). Perceived organizational support and leader-member exchange: A social exchange perspective. Academy of Management Journal, 40(1), 82-111.

Weberg, D. R. (2013). Complexity leadership theory and innovation: A new framework for innovation leadership. Arizona State University. Retrieved from https://repository.asu.edu/attachments/110641/content/ Weberg_asu_0010E_13043.pdf

Weerakoon, C., McMurray, A., Rametse, N., \& Arenius, P. (2019). Knowledge creation theory of entrepreneurial orientation in social enterprises. Journal of Small Business Management, 1-37.

Weinstein, N., Przybylski, A. K., \& Ryan, R. M. (2012). The index of autonomous functioning: Development of a scale of human autonomy. Journal of Research in Personality, 46(4), 397-413. doi: $10.1016 /$ j.jrp.2012.03.007

Wiklund, J., \& Shepherd, D. (2005). Entrepreneurial orientation and small business performance: a configurational approach. Journal of Business Venturing, 20(1), 71-91. doi: 10.1016/j.jbusvent.2004.01.001

Zaech, S., \& Baldegger, U. (2017). Leadership in start-ups. International Small Business Journal, 35(2), 157-177.

Zahari, I. B., \& Shurbagi, A. M. A. (2012). The effect of organizational culture and the relationship between transformational leadership and job satisfaction in petroleum sector of Libya. International Business Research, 5(9), 89-97. doi: 10.5539/ibr.v5n9p89

Zaheer, A., ur Rehman, K., \& Ahmad, A. (2006). Organizational culture assessment of small \& medium-sized enterprises. 11(2), 155-167.

Zehir, C., Müceldili, B., \& Zehir, S. (2012). The impact of corporate entrepreneurship on organizational citizenship behavior and organizational commitment: Evidence from Turkey SMEs. Procedia-Social and Behavioral Sciences, 58, 924-933.

Zhao, X., Lynch Jr, J. G., \& Chen, Q. (2010). Reconsidering Baron and Kenny: Myths and truths about mediation analysis. Journal of Consumer Research, 37(2), 197-206. 


\section{Appendix-A}

Dimensions and Items of Survey Questionnaire Used in the Study

\begin{tabular}{|c|c|}
\hline & Organizational Culture \\
\hline \multirow{4}{*}{ 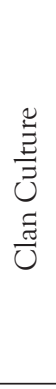 } & $\begin{array}{l}\text { Our firm is a very personal place. It is like an extended family. People seem } \\
\text { to share a lot of themselves. }\end{array}$ \\
\hline & $\begin{array}{l}\text { The top managers of our firm are generally considered to be mentors, sages, } \\
\text { or father or mother figures. }\end{array}$ \\
\hline & $\begin{array}{l}\text { The glue that holds our firm together is loyalty and tradition. Commit- } \\
\text { ment to this firm runs high. }\end{array}$ \\
\hline & $\begin{array}{l}\text { Our firm emphasizes human resources. High cohesion and morale in the } \\
\text { firm is important. }\end{array}$ \\
\hline \multirow{4}{*}{ 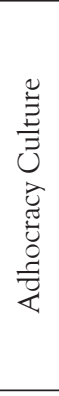 } & $\begin{array}{l}\text { Our firm is a very dynamic and entrepreneurial place. People are willing to } \\
\text { stick their necks out and take risks. }\end{array}$ \\
\hline & $\begin{array}{l}\text { The top managers of our firm are generally considered to be entrepreneurs, } \\
\text { innovators, or risk takers. }\end{array}$ \\
\hline & $\begin{array}{l}\text { The glue that holds our firm together is commitment to innovation and } \\
\text { development. There is an emphasis on being first. }\end{array}$ \\
\hline & $\begin{array}{l}\text { Our firm emphasizes growth and acquiring new resources. Readiness to } \\
\text { meet new challenges is important. }\end{array}$ \\
\hline \multirow{4}{*}{ 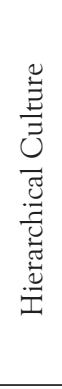 } & $\begin{array}{l}\text { Our firm is a very formalized and structured place. Established procedures } \\
\text { generally govern what people do. }\end{array}$ \\
\hline & $\begin{array}{l}\text { The top managers of our firm are generally considered to be coordinators, } \\
\text { organizers, or administrators. }\end{array}$ \\
\hline & $\begin{array}{l}\text { The glue that holds our firm together is formal rules and policies. Maintain- } \\
\text { ing a smooth running institution is important here. }\end{array}$ \\
\hline & $\begin{array}{l}\text { Our firm emphasizes permanence and stability. Efficient and smooth opera- } \\
\text { tions are important. }\end{array}$ \\
\hline \multirow{4}{*}{ 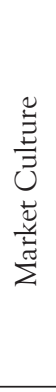 } & $\begin{array}{l}\text { Our firm is very production oriented. A major concern is with getting the } \\
\text { job done, without much personal involvement. }\end{array}$ \\
\hline & $\begin{array}{l}\text { The top managers of our firm are generally considered to be producers, } \\
\text { technicians, or hard drivers. }\end{array}$ \\
\hline & $\begin{array}{l}\text { The glue that holds our firm together is the emphasis on tasks and goal } \\
\text { accomplishment. A production orientation is commonly shared. }\end{array}$ \\
\hline & $\begin{array}{l}\text { Our firm emphasizes competitive actions and achievement. Measurable } \\
\text { goals are important. }\end{array}$ \\
\hline & Entrepreneurial Orientation \\
\hline
\end{tabular}




\begin{tabular}{|c|c|}
\hline \multirow{3}{*}{ 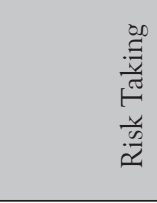 } & Our firm stresses a fully delegated policy for employees. \\
\hline & Our firm gives the freedom for individuals or teams to develop new ideas. \\
\hline & $\begin{array}{l}\text { In general, the top managers of our firm have a strong tendency to be ahead } \\
\text { of others in introducing novel ideas or products/services. }\end{array}$ \\
\hline \multirow{3}{*}{ 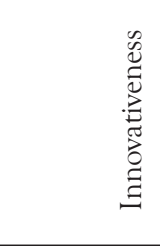 } & $\begin{array}{l}\text { Our firm encourages and stimulates technological, product/service-market, } \\
\text { and administrative innovation. }\end{array}$ \\
\hline & Our firm stimulates creativity and experimentation. \\
\hline & $\begin{array}{l}\text { Our firm's innovative initiatives are hard for competitors to successfully } \\
\text { imitate. }\end{array}$ \\
\hline \multirow{2}{*}{ 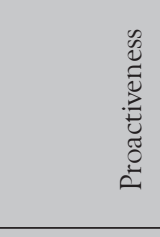 } & $\begin{array}{l}\text { In dealing with competitors, our firm typically initiates actions that compet- } \\
\text { itors respond to. }\end{array}$ \\
\hline & $\begin{array}{l}\text { In dealing with competitors, our firm is very often the first business to } \\
\text { introduce new products/services, administrative techniques, operating } \\
\text { technologies, etc. }\end{array}$ \\
\hline \multicolumn{2}{|r|}{ Entrepreneurial Leadership } \\
\hline \multicolumn{2}{|c|}{$\begin{array}{l}\text { The leadership in this firm often comes up with radical improvement ideas for the products/ser- } \\
\text { vices we are selling }\end{array}$} \\
\hline \multicolumn{2}{|c|}{$\begin{array}{l}\text { The leadership in this firm often comes up with ideas of completely new products/services that we } \\
\text { could sell }\end{array}$} \\
\hline \multicolumn{2}{|r|}{ The leadership in this firm is a risk taker } \\
\hline \multicolumn{2}{|r|}{ The leadership in this firm is creative } \\
\hline \multicolumn{2}{|r|}{ The leadership in this firm is passionate about his/her work } \\
\hline \multicolumn{2}{|r|}{ The leadership in this firm is a visionary } \\
\hline \multicolumn{2}{|c|}{ The leadership in this firm challenges and pushes me to act in a more innovative way } \\
\hline \multicolumn{2}{|c|}{ The leadership in this firm wants me to challenge the current ways we do business } \\
\hline \multicolumn{2}{|r|}{ The leadership in this firm is patient } \\
\hline & The leadership in this firm is flexible \\
\hline
\end{tabular}

